顕微鏡手術から視鏡下手術へのパラダイムシフト

木下 学, 木嶋 教行, 香川 尚己, 貴島 晴彦

大阪大学大学院医学系研究科脳神経外科

\title{
The Exoscope Paradigm Shift in Neurosurgery
}

\author{
Manabu Kinoshita, M.D., Ph.D., Noriyuki Kijima, M.D., Ph.D., Naoki Kagawa, M.D., Ph.D., and \\ Haruhiko Kishima, M.D., Ph.D.
}

Department of Neurosurgery, Osaka University Graduate School of Medicine

The surgical microscope has been the gold-standard visual equipment for neurosurgical procedures since its introduction in the 1960s. Although it undoubtedly has made enormous contribution to the field, this medical device still offers room for improvement. In particular, physical size and weight restrict the relationship between surgeons and patient positions. The exoscope is a newly developed medical tool for microneurosurgery. The fundamental concept of this device is to provide excellent ergonomics during neurosurgical procedures while preserving the numerous advantages that surgical microscopes provide to surgeons. It is composed of a small stereo camera and a $4 \mathrm{~K}$ three-dimensional large display. Although its clinical impact remains debatable, this device may completely replace surgical microscopes in the coming years. The exoscope enables:

1. shallow-angle surgical approaches without compromising the surgeon posture;

2. assistance in deep-seated surgical fields;

3. the collection of three-dimensional surgical field data with quantitative measurement of surgical maneuvers.

This review article provides an overview of the advantages mentioned above using clinical cases operated with exoscope assistance to help understand its clinical and technological impact on neurological surgery.

(Received August 24, 2020; accepted October 1, 2020)

Key words: surgical microscope, exoscope, three-dimensional data

Jpn J Neurosurg（Tokyo）30: 199-207, 2021

\section{はじめに}

手術用顕微鏡の導入により, 近代脳神経外科手術は飛 躍的な技術的進歩を遂げた。脳神経外科医は直視下でし か脳組織や脳血管が観察できなかった環境から，よく照 明された立体的術野を得られるようになり，微細で愛護 的な手術を行うことが可能となった。また微小解剖学と
いう新しい外科治療研究分野も発展し, 顕微鏡手術の発 展に大きく寄与した. よって, 手術用顕微鏡は単なる「拡 大照明鏡」という道具にとどまらず，それまでの時代に はなかった「新しい外科治療の考元方」を脳神経外科学 に提供してくれた，パラダイムシフトを引き起こした手 術器具といえる。しかしながら, パラダイムシフトが起 きるような技術革新時には，新規技術に対する懐疑心や 

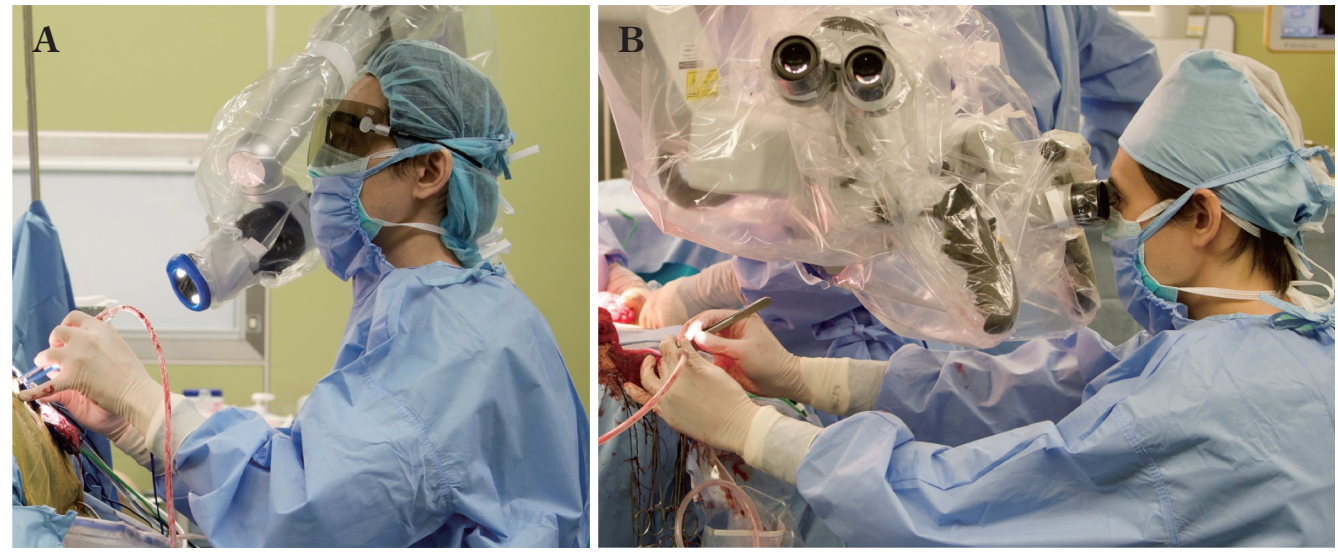

Fig. 1 Comparison of surgeon's posture between using an exoscope and a surgical microscope

The surgeon's postures in shallow-angle surgical approaches using an exoscope (A) and a surgical microscope (B) were compared. The surgical microscope forces the surgeons to extend their arms in shallow-angle surgical approaches (B), while an exoscope provides a comfortable surgical posture (A).

反発が少なからず生じる。手術用顕微鏡の導入に尽力さ れた Yaşargil 先生や菊池晴彦先生らはそれまでの肉眼的 脳神経外科手術に慣れ親しんでいた諸先輩先生からの批 判に耐えながら，脳神経外科における手術用顕微鏡の普 及に努め, その可能性を説いて回られたと聞く ${ }^{5) 7}$. この ような先人たちの苦労とフォロワーたちのさらなる開拓 によって発展した脳神経外科顕微鏡手術であるが，数年 前に神経外視鏡 (exoscope) の臨床現場への導入が始まっ た。本総説では手術用顕微鏡に対する(1)神経外視鏡の利 点，(2)神経外視鏡の手術への応用，(3)神経外視鏡の手術 教育への応用, さらに(4)長期的な視野に立つた手術機器 開発に神経外視鏡が及ぼす影響と可能性について述べる。

\section{手術用顕微鏡の問題点と神経外視鏡による 問題点の解決}

手術用顕微鏡は脳神経外科手術に必須の医療機器であ り，顕微鏡手術手技を磨くことが脳神経外科医の技術的 な鍛鍊そのものである。しかしながら，手術用顕微鏡そ のものに改善が期待される点がないわけではない，脳神 経外科手術では患者の体位がその後の手術操作に大きく 影響することが知られている。患者体位と術者体位は脳 神経外科医が熟知しておくべき事項であるが，これは手 術用顕微鏡が比較的大きな医療機器であり, 可動性にも 制限があることに起因する。顕微鏡手術では垂直軸を中 心に，およそ 30 度程度までの仰角に顕微鏡の視軸変動 をとどめることが理想的であり，それを超えると術者に
とつて辛い手術姿勢となる。松果体手術の supra cerebel一 lar infratentorial appoach は水平方向の視軸を要求するが, 術者にとって疲労感の強い術式であることは有名であ る。神経外視鏡はこの問題点を解決するべく開発された 医療機器である。顕微鏡の対物レンズが小さなカメラと なり，接眼レンズが $4 \mathrm{~K}$ 立体モニターとなった。神経外 視鏡は顕微鏡手術とは異なったハンドアイコーディネー ションを要求するため, 従来の顕微鏡術者にとつては多 少の慣れを要求することは事実である。しかしながら, 顕微鏡と比較して対物レンズの役割を果たすカメラが小 型であるため, 水平視軸の観察が容易であるうえに, 術 者はモニ夕ーを見るため，いかなる術野であっても手術 姿勢は変わらないという変えがたい利点を神経外視鏡は 提供する（Fig. 1A)。また $4 \mathrm{~K}$ 立体モニターが提供する術 野の没入感はあたかも显微鏡を咞いて術野を観察してい るかのような錯覚すら覚えさせるものである。 3D で映 像が提供されている映画を鑑賞したことがある読者であ れば，3D 映像が提供する映像への没入感と臨場感は容 易に理解できよう。神経外視鏡は本体とモニ夕ーを含め て比較的コンパクトな構成になっており手術室を占有す るスペースは手術用顕微鏡のそれより小さくなる，以下 に神経外視鏡を用いた手術について具体的に説明する。

\section{神経外視鏡の利点を生かした 脳神経外科手術の 1 例}

神経外視鏡を使用した脳神経外科手術の 1 例を提示 


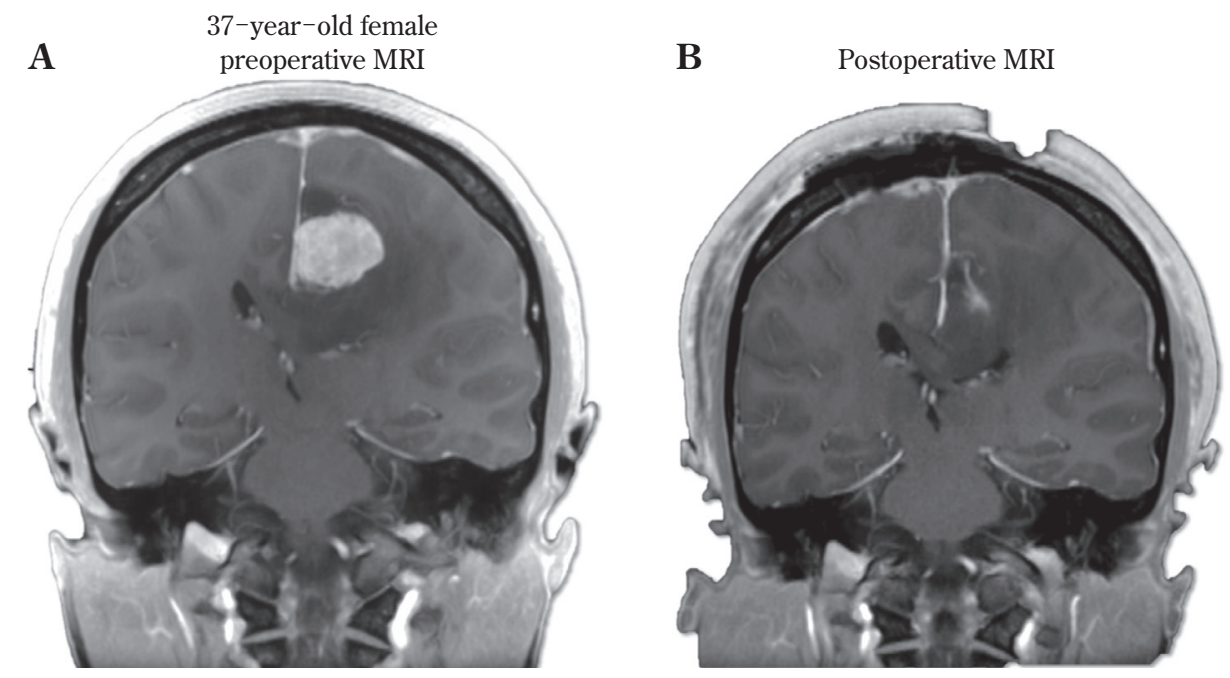

Fig. 2 A representative case requiring a shallow ${ }^{-}$angle surgical approach

Left falx meningioma with peritumoral brain edema. The contralateral anterior interhemispheric approach was adopted to remove the tumor, allowing gross total resection (Simpson's Grade 1 resection).

し，この医療機器の利点について考察する．提示症例は 視野障害と頭痛を主訴とした 37 歳の女性である.MRI で左大脳鎌髄膜腫と思わ机る頭蓋内占拠性病変を認め, 左大脳半球は広範な浮腫性変化をきたしていた（Fig. $2 \mathrm{~A})$ ，筆者らは同側（左側）からの正中進入では腫瘍最 外側下面で正常脳組織と腫瘍の剝離が難しくなること, ならびに左側進入では，すでに浮腫性変化をきたしてい る大脳を牽引し, 術後脳浮腫を増悪させる危険性がある ことを考慮し, 対側（右側）経大脳鎌進入が有利である と考えた。また，進入側大脳を重力で自然牽引できれば 脳べラで常時脳組織を圧迫する必要もなく, 十分な手術 操作空間が確保できるだろうと思われた（Fig. 3A）。実 際の手術ではこの考え方に則り, 右側卧位として右側正 中付近に開頭を設け, 大脳鎌経由で腫瘍に接近した (Fig. 3B)。術前の想定どおり, 手術の進行とともに右大脳は 重力によって自然と術野外 (下方) へ偏位し, 腫瘍摘出 に必要な操作空間が十分に確保できた。腫瘍を十分に内 減圧したのちの手術終盤では, 仮に同側進入を採用して いれば，視認がもっと難しかったであろう，腫瘍最外側 下面の剝離面も容易に視認することができ, 内減圧後の 腫瘍を一塊に摘出できた (Fig. 3C F ) 。術後 MRIでは術 前に見られた左大脳浮腫は軽快傾向であることを確認で きている (Fig. 2B).

正中病変に対する対側進入・経大脳鎌接近法はこれま でにもたびたびその有用性が指摘されてきた23)6)8). 重 力による進入側脳の自然牽引を利用することで正常脳組 織に対して愛護的な手術ができることと, 深部外側の術
野展開が容易であることがその特筆すべき利点とされ る。しかしながら, 同術式は術者に無理な手術姿勢を強 いるという決定的な欠点も認識されている. 病変への進 入角度がきわめて浅くなるため, (1)患者の頭位を 60 度 程度挙上する必要がある, (2)術者は水平に近い手術姿勢 を確保する，という技術的なハードルを解決する必要が ある.引用文献での筆者らと查読者らとのやりとりをみ ても，查読者の 1 人は「本術式は魅力的であるが，術者 の毀損された手術姿勢が大きな問題である」と指摘して いる3 .これに対して提示症例は頭位を 45 度程度しか挙 上していない，その一方で術者の姿勢はきわめて自然で あり, 腕が適切に曲がり, 手指を使って手術器具の術野 内での固定もできている。これは神経外視鏡手術では顕 微鏡手術のように医療機器によって強制的に術者の頭部 が術野後方へ押しやられる必要がなく, 術者はしつかり と術野近くに体を近づけることができるからである。比 較対照に同一視軸での顕微鏡手術時の手術姿勢を示す (Fig. 1B)。腕はほぼ伸び切り, 術野内での器具操作は手 先でしか行えないことがわかる。脳を重力牽引し術野を 確保することと，手術視軸が浅くなることは表裏一体の 関係にあるため，神経外視鏡はこれまで前述の手術体位 の制限から実行が困難と思われた術式が沉用化されるよ うなパラダイムシフトを引き起こす可能性がある. 

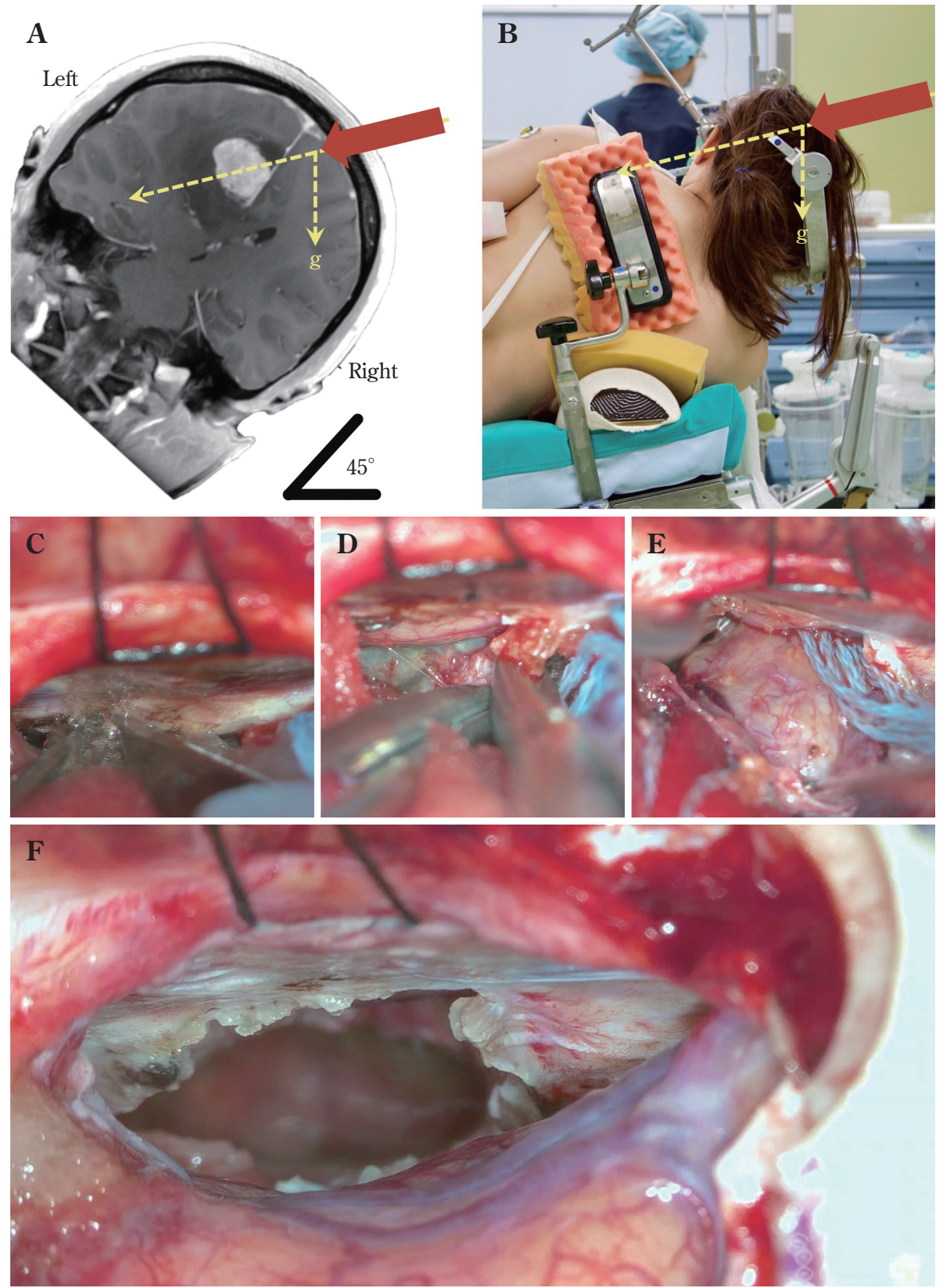

Fig. 3 Surgical considerations for the case presented in Fig. 2

The patient was placed in a right-side-down lateral position with the head elevated to $45^{\circ}$. Gravity retraction allows the right cerebral hemisphere to separate from the surgical route $(\mathbf{A})$. The contralateral transfalcine approach mandates a shallow-angle surgical approach (B). After dural opening, the falx was cut (C, D), and the tumor became visible. It was circumferentially dissected from the cingulate gyrus after internal debulking (E). Gravity retraction enabled retractor-free surgery during the entire procedure $(\mathbf{F})$.

\section{神経外視鏡の利点を生かした 脳神経外科手術教育}

神経外視鏡を使用した脳神経外科手術教育の 1 例を提 示し，この医療機器がこれからの脳神経外科手術の技術
伝承に及ぼす影響の利点について考察する．提示症例は ふらつきを主訴とした 66 歳の女性である. MRIで第 4 脳 室に腫瘍性病変を認め，脳血管撮影でこの腫瘍性病変は 血管芽腫と診断された（Fig. 4A，B）。この症例は左側臥 位の小脳延髄裂接近法（trans-cerebellomedullary fissure 

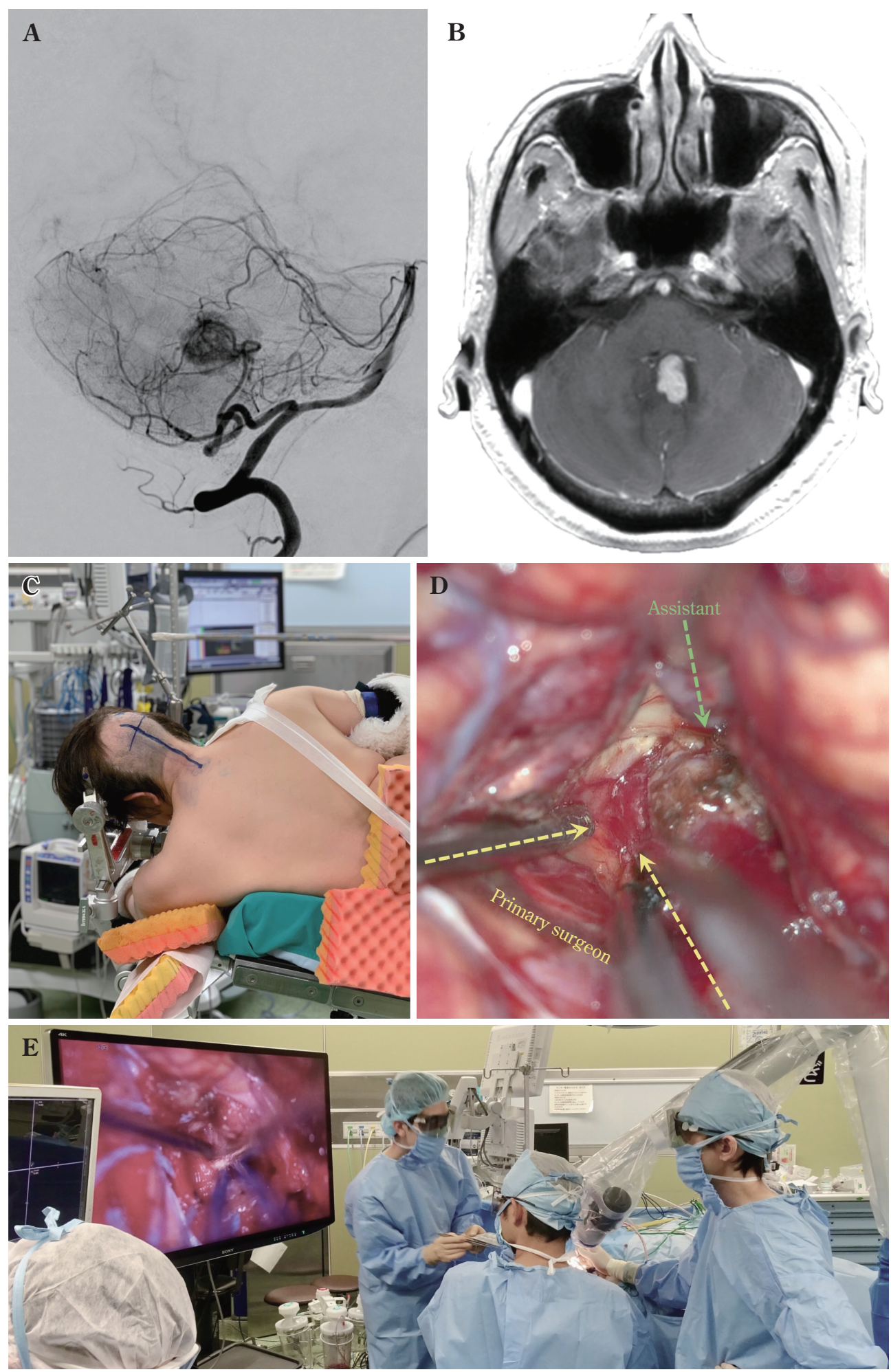

Fig. 4 A representative case using the exoscope for direct surgical education This is a case of a 66-year-old woman harboring a hemangioblastoma in the 4th ventricle $(\mathbf{A}, \mathbf{B})$. The tumor was removed via the trans-cerebello-medullary fissure approach. The patient was placed in a left-side-down park-bench position with the head facing the floor $(\mathbf{C})$. It was possible to directly assist the inexperienced junior surgeons from the right side of the patient (D). The exoscope allows the assisting surgeon to stand behind the primary surgeon sharing the surgical monitor $(\mathrm{E})$. 

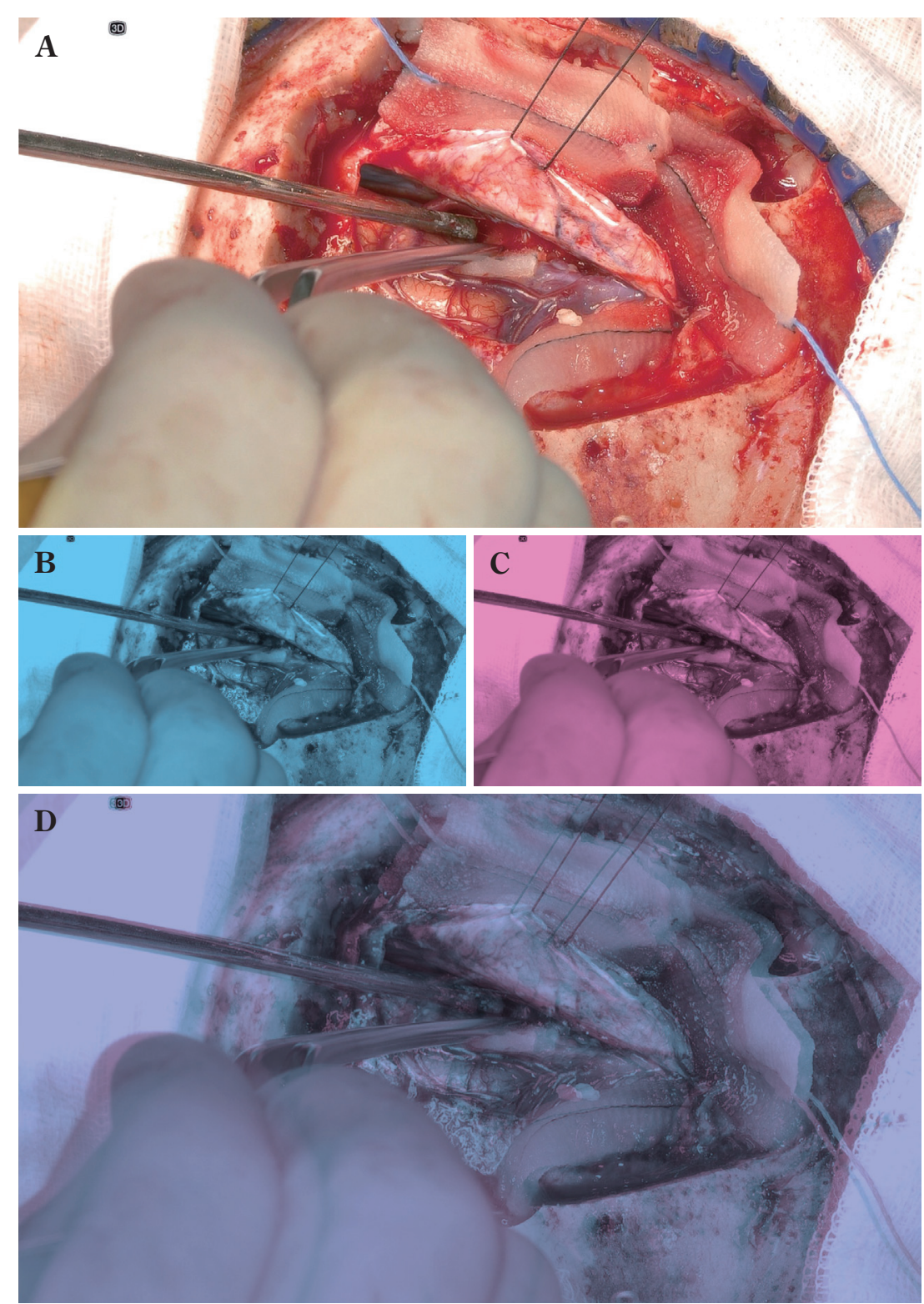

Fig. 5 Stereo image capture via exoscope

Illustration of the basic principle of stereo image capture via an exoscope. Approaching a falx meningioma via the ipsilateral interhemispheric approach (A). The exoscope captures the surgical field using both the cameras on the left $-(\mathbf{B})$ and right- ${ }^{-}$C $)$sides. The three-dimensional stereo image is reconstructed by combining these two images (D).

approach) で行った ${ }^{1)}$ (Fig. 4C)。この手術は本術式の経験 者が未経験者を支援する環境で行った。小脳延髄裂接近 法は術野が深く狭いため, 助手が術者を病変付近で直接 支援することは容易ではない。しかしながら，神経外視 鏡は術者と助手が同一のスクリーンで術野を共有するこ とができるだけでなく，神経外視鏡のカメラが小型であ ることを十分に利用することで助手が術者の後方に位置 することができるため，助手が容易に術野にアクセスす
ることができる，そのため，この症例では助手の吸引管 は右小脳扁桃を圧排し病変へ術者を誘導することができ た (Fig. 4D, E)。このような手術支援は従来の手術顕微 鏡では実現が困難であり,やや難度が高い術式を直接手 術現場で指導し知識と技術を伝承することは難しかった。 神経外視鏡はこのような手術教育現場での問題を解決 し，次世代の脳神経外科医の手術習得速度を加速させる ようなパラダイムシフトを引き起こすことが予想される。 

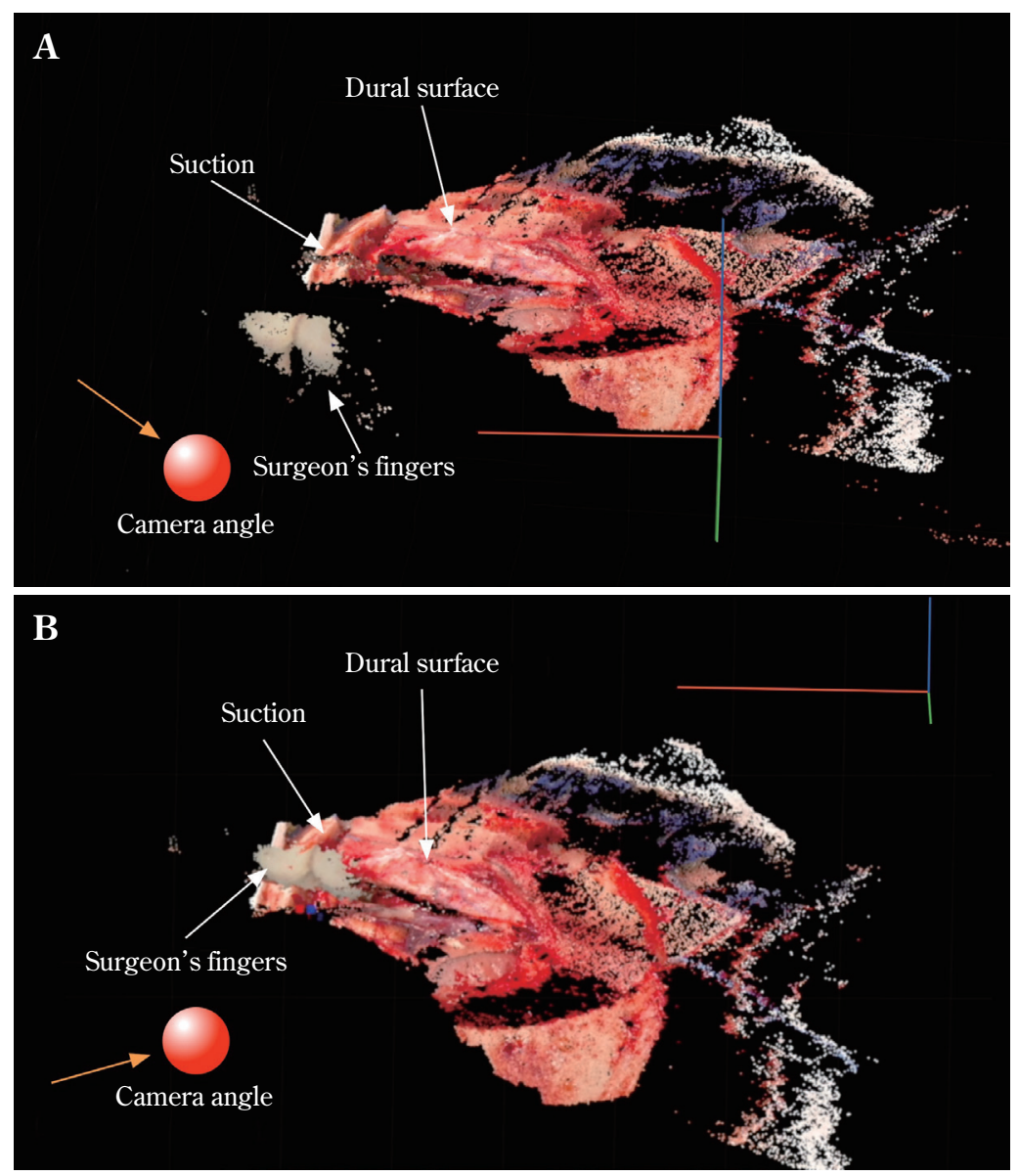

Fig. 6 Three-dimensional depth reconstruction via stereo images

The stereo image in Fig. $\mathbf{5}$ was processed to obtain depth information and embed it in the three-dimensional image. The three-dimensional relationships between the surgeon's fingers, suction, and dural surface were successfully recovered. A pair of still stereo images reconstructed different views with different camera angles $(\mathbf{A}, \mathbf{B})$ as if the still images were taken in three dimensions.

\section{神経外視鏡が引き起こす 脳神経外科手術機器のパラダイムシフト}

神経外視鏡は術野を小型カメラが撮影し映像を $4 \mathrm{~K}$ 立 体モニターに投影し術者に立体的な術野を提供すること を述べた。 $2 \mathrm{~K}$ 解像度で左右の独立したカメラで撮影さ れた映像が「立体映像」としてモニター上で再現される が，記録装置にはこの左右の撮影映像が常時録画され る. 従来の手術用顕微鏡でも術野は録画され, 仕様に よっては 3D の立体映像として記録していることもあっ た。しかしながら, 顕微鏡手術で記録された映像は実際 に術者が術中に観察している映像ではなく, 接眼レンズ へ投影される術野の一部分を別光路に分配し CCD カメ ラで捉えた映像である。その一方で, 神経外視鏡手術で は手術は CCD カメラが捉えた映像そのものを「術野」と
して利用するため, 記録装置に保存された映像は,「まさ に術野そのもの」ということになる。術野そのものが 4 次元デジタル情報として記録されるのは初めてのことで あり，今後この情報がさまざまなかたちで手術教育や医 療機器開発に応用されていくことが予想される. 本論文 では 1 例として神経外視鏡の記録映像を用いた術野の 3 次元再構築を提示する.

提示症例は病側進入で摘出術を行った大脳鎌血管周皮 腫の症例である (Fig. 5A). 開頭し硬膜切開直後の術野 を神経外視鏡が撮影した場面であるが, 左右独立カメラ が術野をわずかな視差を維持して撮影している（Fig. $5 \mathrm{~B} \sim \mathrm{D})$. 撮影時の焦点距離, 視差角度, 拡大率という既 知のパラメー夕を用いて, 左右カメラが撮影した画像を 解析すれば，術野の深度情報を回収することができる (Fig. 6).この例では Fig. 5 で示した静止画をまるで立体 
的に術野を観察したかのように再現することができる。

Fig. 6 は Fig. 5 を画像解析することにより異なった角度 から術野を観察した際の光景を再構成したものである.

神経外視鏡はこのような 3 次元情報を経時的に記録し ているため, 手術手技の定量化が可能になる可能性があ る。手術手技を定量化し，デジタルデー夕化することは 手術教育教材の作成に役立つだけなく，ロボット手術を 実現化するために必要なソースデー夕を確保できること になる。数十年後に振り返ったときに神経外視鏡が脳神 経外科手術機器開発にもたらした影響は計り知れないも のになるのではないかと思われる。

\section{おわりに}

脳神経外科手術に手術用顕微鏡が初めて導入されたの は 1960 年頃とされる ${ }^{4)}$. 当初は非力で可動性も乏しかっ た手術用顕微鏡は先人たちの絶え間ない努力と工夫で今 では脳神経外科手術に必須の医療機器となった。手術用 顕微鏡は医療機器としての技術的発展とともに微小解剖 学という学術分野を花開かせ, Cushing 先生らが活躍さ れていた 100 年前の脳神経外科医療を一変させた。本稿 で供覧した神経外視鏡はちょうど 60 年前の手術用顕微 鏡初号機に相当する。神経外視鏡は手術用顕微鏡に取っ て代わるべく開発された医療機器であるが，その使用感 は手術用顕微鏡とかなり異なる。初めて神経外視鏡で手 術を行うと，その使用感の異なりに術者は相当とまどう ことになる，よって，明らかに神経外視鏡手術には顕微 鏡手術とは別のラーニングカーブが存在する．また，神 経外視鏡は手術用顕微鏡の代用機を目指すという開発思 想から，神経内視鏡が可能とするような深部手術には向 かないことに留意する必要がある。このような医療機器 としての限界はあるものの，神経外視鏡は今後多くの医 療機関に導入され，さまざまなユーザー（われわれ脳神 経外科医）の意見を取り入れながら改良されていくこと
は確実だろうし，この医療機器から派生する医学知見も 多彩なものになろう。手術用顕微鏡に取って代わる技術 革新である神経外視鏡のこれらの未来を占ううえで本稿 が一助になれば幸いである。

\section{COI}

著者全員は日本脳神経外科学会への COI 自己申告の登録を 完了しています、本論文に関して開示すべき COI はありませ L.

\section{文 献}

1）安部 洋，福田健治，大川将和，野中 将，勝田俊郎， 東登志夫，竹本光一郎，阪元政三郎，岩朝光利，井上 亨：Trans-cerebellomedullary fissure approach の有用性。 脳外誌 $24: 761-769,2015$.

2) Bohnstedt BN, Kulwin CG, Shah MV, Cohen-Gadol AA : Posterior interhemispheric transfalcine transprecuneus approach for microsurgical resection of periatrial lesions : indications, technique, and outcomes. J Neurosurg 123: 1045-1054, 2015.

3) Hafez A, Raygor KP, Lawton MT: Contralateral anterior interhemispheric approach to medial frontal arteriovenous malformations : surgical technique and results. Oper Neurosurg (Hagerstown) 13: 413-420, 2017.

4) Kurze T: Microtechniques in neurological surgery. Clin Neurosurg 11: 128-137, 1964.

5）菊池晴彦：マイクロサージェリーの黎明期。日本脳神経 外科学会正史委員会編：日本脳神経外科学会正史. 東京, 日本脳神経外科学会, 2020 , pp. 50 .

6) Lawton MT, Golfinos JG, Spetzler RF : The contralateral transcallosal approach : experience with 32 patients. Neurosurgery $39:$ : 729-734, 1996.

7) Yasargil MG: Microneurosurgery, Volume I : Microsurgical Anatomy of the Basal Cisterns and Vessels of the Brain, Diagnostic Studies, General Operative Techniques and Pathological Considerations of the Intracranial Aneurysms. New York, Thieme, 1984

8) Zaidi HA, Chowdhry SA, Nakaji P, Abla AA, Spetzler RF : Contralateral interhemispheric approach to deep-seated cavernous Malformations : surgical considerations and clinical outcomes in 31 consecutive cases. Neurosurgery $\mathbf{7 5}$ : 80-86, 2014 
顕微鏡手術から視鏡下手術へのパラダイムシフト

木下 学 木嶋 教行 香川 尚己 貴島 晴彦

1960 年代初頭の導入時期を経て, 手術用顕微鏡は脳神経外科手術に必須の医療機器となった. 手術 用顕微鏡が脳神経外科診療に多大な貢献をしたことは疑いの余地がないが，医療機器として改善する べき点がないわけではない. 手術用顕微鏡には相当の物理的な体積と重量があるために, 手術の際に 術者と患者の体位の相関関係にある一定の制限がかかってしまう．このような問題点を解決するべく 神経外視鏡が開発され，臨床現場に導入されはじめている．本総説では神経外視鏡が手術用顕微鏡を 凌駕する可能性について実際の症例提示を通して概説する.

脳外誌 $30 ： 199-207 ， 2021$ 